Esposito, G., D'Elia, F., \& Raiola, G. (2020). A Method to Promote the Development of Intelligence and Game Skills in Youth Football. Teoriâ ta Metodika Fizičnogo Vihovannâ, 20(3), 142-148. https://doi.org/10.17309/tmfv.2020.3.03

\title{
A METHOD TO PROMOTE THE DEVELOPMENT OF INTELLIGENCE AND GAME SKILLS IN YOUTH FOOTBALL
}

\author{
Giovanni Esposito $^{1 \mathrm{ABCDE}}$, Francesca D’Elia ${ }^{1 \mathrm{ABCD}}$, Gaetano Raiola ${ }^{\mathrm{ABCE}}$, \\ ${ }^{1}$ University of Salerno \\ Authors' Contribution: A - Study design; B - Data collection; C - Statistical analysis; D - Manuscript Preparation; E - Funds Collection
}

Corresponding Author: Giovanni Esposito, E-mail: g.esposito198@studenti.unisa.it

Accepted for Publication: September 20, 2020

Published: September 25, 2020

DOI: 10.17309/tmfv.2020.3.03

\begin{abstract}
Research purpose. The aim of the study is to evaluate the playing skills of the young players under investigation in a global context. Specifically, it is intended to test whether the proposed training methodology favorably influenced the development of game skills, increasing the efficiency of game performance.

Materials and methods. The study participants are 24 young players, aged between 13 and 14.To achieve the tasks set, the study relied on the following methods: analysis of scientific literature, field testing and methods of mathematical statistics. The experimental group performed a specific training mesocycle (that of the Brain Kinetic), while the control group performed a traditional working mesocycle. To detect the effects of the training methodologies, field tests were used both before and after the training period, respecting the execution protocols described by H. Wein. The study materials were processed by the statistical analysis software-IBM SPSS 22. A paired sample t-test was used to compare the results of the two groups.

Results. The t-test analysis indicates statistically significant changes in the training effect of the experimental group. A better performance index found in the experimental group in the execution of skills, compared to the control group, is due to the diversification of the methodology to which they were subjected. Therefore, the changes after training at each skill index are amplified by the subsequent repetition of the tests. Differences between test indicators are statistically significant.

Conclusions. The study, through the use of field tests, has confirmed the hypothesis that the use of the Brain Kinetic training method determines a positive training effect in skill exercises. This method allowed the players involved in the experimental group to take personal, individual and group actions that had a real impact on the outcome of the game. Keywords: youth football, decision-making skills, simplified game.
\end{abstract}

\section{Introduction}

Talent is a somewhat difficult concept to understand, precisely because it is possible to experience it in many different forms (Battisti, 2018). The task of a coach within a football team, or any other sports discipline, is precisely to identify this talent and place it in an existing context, the team (Accame, 2010). Since there is no exact science to accurately quantify an athlete's talent, each coach uses various approaches to investigate what are the factors that determine performance (Invernizzi, Signorini, Bosio, Raiola \& Scurati, 2020). According to several studies, through the functional evaluation and the use of specific tests, it is possible to measure certain variables in team sports, such as physical condition or technical-tactical performance (Ceruso, Esposito,

(C) Giovanni Esposito, Francesca D’Elia, Gaetano Raiola, 2020.
\& D’Elia, 2019; Izzo, D'isanto, Raiola, Cejudo, Ponsano, \& Varde'i, 2020). The trainer must be able to observe and understand the needs of the young players, improve their shortcomings, enhance their qualities, and subsequently help to define the purposes necessary to set up the training program (MacDougall, Wenger, \& Green, 1991). To improve the technical level, it is necessary, among other things, to systematically stimulate the development of the player's technical and tactical thinking and behaviour, while improving perceptual and individual skills (Esposito, Ceruso, \& D'Elia, 2019). Using these properly constructed experiences, allows to achieve correct behaviours in the various situations of life, as well as in football (Raiola, D'Elia, \& Altavilla, 2018). The ability to quickly and effectively adapt a learned behaviour, can only be acquired when the player has been subjected to a systematic development of his intellectual abilities, from the beginning, and up to the high performance phase (Raiola, 2017). As 
widely recognized, all young people should face simplified games as soon as possible during training, which are the ideal means of transmitting tactical knowledge and experience for the correct execution of technical and tactical skills (D'Isanto, D'Elia, Raiola, \& Altavilla, 2019). The acquisition of knowledge and experience is the result of a well-studied pedagogical process in which the instructor, by means of clarifying questions and demonstrations to the boys, aims to make visible and clear all the knowledge and experiences learned by the boys themselves (Molinas \& Argiolas, 2002; Rossi, Thrassou, \& Vrontis, 2013). With a progressive games program, tactical thinking and behavior are developed as each player encounters and experiences the various solutions available to him (Williams \& Reilly, 2000). It does not matter if the action on the field is the result of the repetitive practice of the same game situation in training, or if it is the correct solution to the problem resulting from the spontaneity of the player. What is important is that the player is able to read the game situation and solve problems successfully (Halouani, Chtourou, Dellal, Chaouachi, \& Chamari, 2017).

Research purpose - in this study it was hypothesized the possibility of increasing the overall performance of a sample of young amateur footballers, through the use of the Brain Kinetic training methodology. The aim is to test the efficiency and impact of this training methodology through the use of field tests validated in the literature. These tests are useful not only to evaluate the level of technical qualification acquired, but also the ability to make decisions. In particular, it was intended to experiment if the proposed method favorably influenced the development of specialist knowledge in the experimental group, after two months, increasing the efficiency of the game performance.

\section{Materials and methods}

\section{Study participants}

Twenty-four U14 players (age: $14 \pm 0.3$ years; height: $166.4 \mathrm{~cm}$; body mass: $62.92 \mathrm{~kg}$; training experience: $(3 \pm 0.3$ years) participated in this study. All participants were free from musculoskeletal injuries, participated in $\geq 95 \%$ of training sessions per year, and were not early or late matures. Experimental procedures and potential risks, discomforts, and benefits were fully explained to all boys and parents/guardians prior to participation. Signed informative consent forms were provided by subjects' parents and/or legal guardians.

\section{Study organization}

The group of players was divided into an experimental and a control group both characterized by 12 players. Both groups performed a different training method twice a week for a period of two months. The training method used to which the experimental group was subjected, involved a whole series of proprioception exercises associated with complex movement sequences, capable of inducing the activation of different cortical areas (motor, somatosensitive) and subcortical areas for the purpose of learning and correct execution of the required motor program (Pill, 2012, 2014; Capranica \& Millard-Stafford, 2011). Some proposals consisted of dribbling regularly with the ball by simultaneously moving a ball on a racket without dropping it; conducting ball exercises wearing a monocular bandage; quick and reasoned response exercises to unexpected events and exercises to improve the autonomy of the limbs and spatial sense. All these exercises were included in the training context, and proposed through sequences of variants, for a total of 46-60 minutes. They were performed 2 twice a week. The control group, instead, took part in a traditional training mesocycle, carrying out in addition to the analytical part, also technique exercises and motor paths. They also performed games with defensive positioning in the first $2 / 3$ of the field within $7 \mathrm{sec}$ onds, giving a limit of 3 ball touches. Both before and after the training period, all 24 players have carried out three different field tests, to evaluate in addition to the components of a technical nature, also other important skills such as game vision, creativity, advance and choice among the various possibilities were used in this study. The tests carried out followed the original test protocols proposed by $\mathrm{H}$. Wein in the literature (Wein, 2007). Specifically, the three tests concerned: the number of consecutive passes made by evading the opposing pressure, a situation of attack with elements of psychokinetic and finally a $3 \mathrm{vs} 3$ game with 4 doors. The tests were carried out on different days.

The first test carried out concerned the number of consecutive passes useful to evade the opposing pressing (Fig.1). Both the control and experimental groups have been divided into four teams, each consisting of three players. The two opposing teams met on an $8 \times 16 \mathrm{~m}$ or $10 \times 20 \mathrm{~m}$ playing field. The test objectives concerned knowing how to pass the ball at the right time, not entering the defender's range of action with the ball, imparting sufficient power and pressure to the ball.

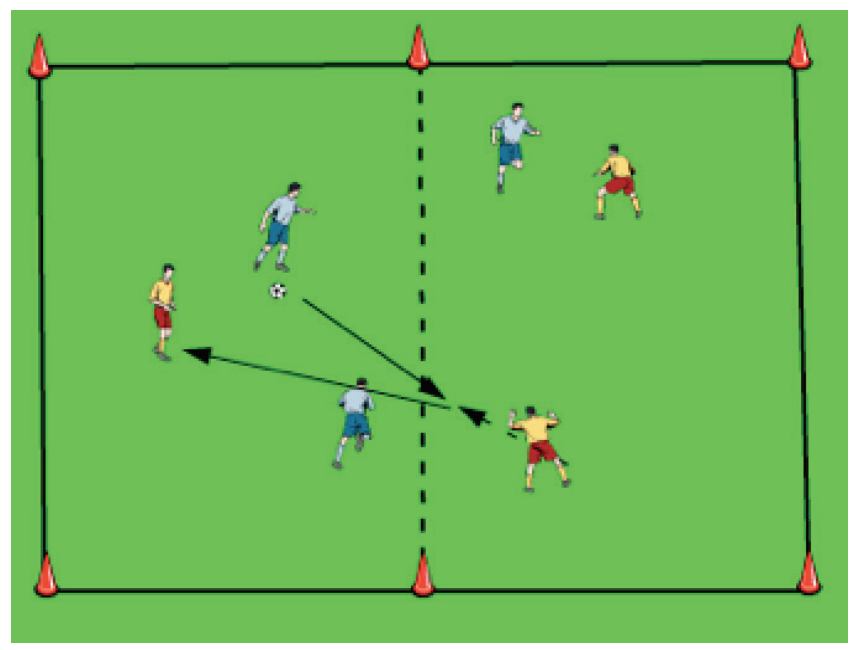

Fig. 1. Scheme of the first test: game of consecutive passes

A team had to place two players in the midfield ( $8 x 8 \mathrm{~m})$, trying to make the maximum number of consecutive passes while an opponent tried to do everything possible to intercept the ball. When the defender was able to intercept the ball, he had to immediately pass it on the adjacent field, of the same size, where two of his teammates waiting for the passage. Thus, a new team of three attackers was formed who had to pass the ball, avoiding the intervention of one of the three opponents, keeping possession for 10-15 sec. Each player, after making a pass and then getting rid of the ball, always had to look for a position on the field that would allow him to re- 
ceive the ball and pass it again without haste. The ball holder had two options: pass the ball to the less marked partner or lead the ball into an undefended space to gain time. In gaining space, the player always had to protect the ball with his body, placing himself between the ball and the opponent, and then turning around and leaving the corner. The defender had to be good at reducing the space and time available to the strikers, anticipating their actions, and forcing them to play the ball in the desired direction. When the ball left the field or when the attackers committed a foul, the defender took a free-throw, with the opponents positioned $5 \mathrm{~m}$ away. The game lasts 4 times of 5 minutes. What was evaluated was the number of consecutive passes that the team managed to make in the 4 game times.

The second test concerned the execution of a three-player attack situation (Fig. 2). In this case, two doors of different colours were needed for each team. The players of the two opposite teams were matched in an organized way (according to the scores of the first test) and competed in four games of $3 \mathrm{vs} 3$. Both the single selected actions (shots on goal, guiding the ball, dribbling / feints, advances on the opponent) and actions in collaboration with a partner (passes, receptions, position taking) were analysed.

Specifically, each team attacked two diagonally opposite doors and defended the other two. By doing so, a situation of

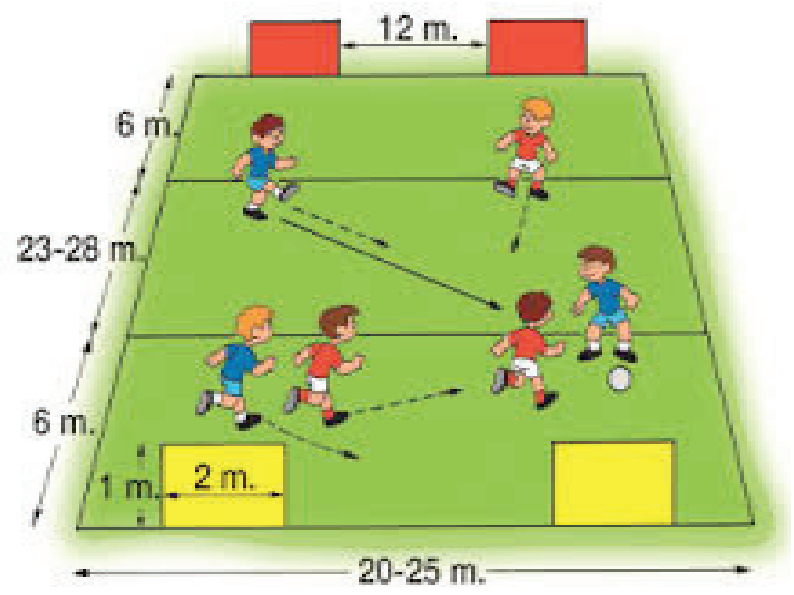

Fig. 2. Scheme of the second test: "3vs3 with elements of psychokinetic"

numerical superiority of 3vs2 and subsequently of 2vs1 was recreated that the team in possession of the ball had to try to capitalize to score a goal. The attack was to be conducted by passing the ball to speed up the game, with better exploitation of the free spaces. The introduction of frequent changes of direction when leading the ball could have created more space and induced more defensive errors. The coach and an assistant were able to change the color of the doors quickly and simultaneously on both sides. In fact, a frequent change of color of the doors during the game allowed to increase the attention, concentration, and peripheral vision of all the engaged players, since they had to keep an eye on all four doors simultaneously and read the game on the field. A goal could be scored either by shooting from within the $6 \mathrm{~m}$ zone, or by leading the ball through the $7 \mathrm{~m}$ goal of the designated color. The duration of the game is 3 times of 3 minutes. Table 2 shows a series of quantitative indices that reflect the perfor- mance of each team. Specifically, these indices concern the number of scoring chances, the number of feints or dribbling, total passes, the number of balls stolen, the right maintenance of the position, the reception and the guide of the ball.

The last test involved a $3 \mathrm{vs} 3$ in confined spaces (Fig. 3). Each team had to defend two opposite doors and attack the other two; the doors were 7 to 10 meters wide, depending on the technical level of the players. Again, the team players, combined in an organized way, were evaluated in four games. In this case, the strikers in possession of the ball were not only required to assess the position, behaviour, and distance of the active defender, but also the position of the passive defender on the goal line. The assessment of the players' operational efficiency was aimed at limiting events that could adversely affect the course of the game.

The game started by throwing the ball in the midfield. When the ball went off the pitch it was put back into play by the other team, with the opponents at least $3 \mathrm{~m}$ away. To

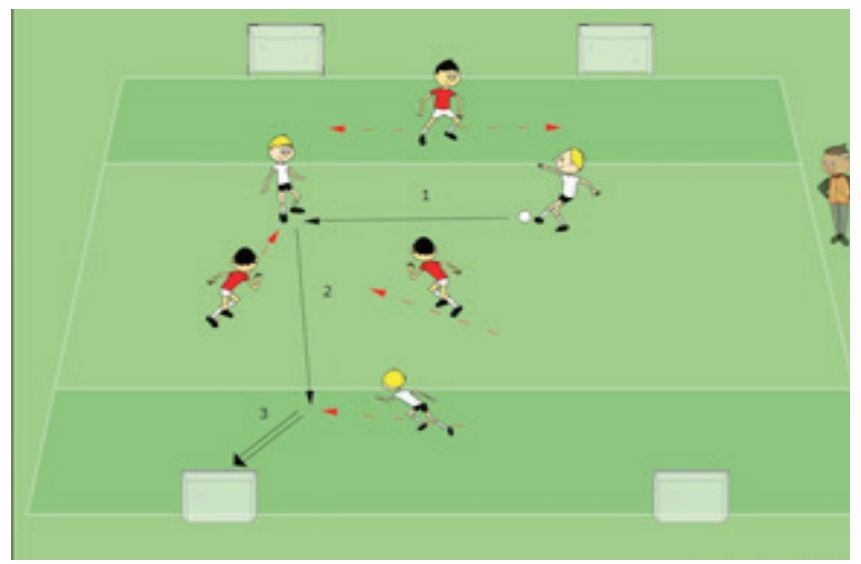

Fig. 3. Scheme of the third test: " $3 v s 3$ in small spaces"

score a goal, the teams had to lead the ball beyond the line of one of the two goals. To obtain a remarkable participation of all the players, it is recommended to make a two-minute rest after two goals (Joo, Hwang-Bo, \& Jee, 2016). During this time both teams could discuss which strategy to apply later in the game. The aim of the test was to evaluate the quality of the game without the ball, the ability to break away and the understanding between the strikers. To create enough space and time to bring the next action to a successful conclusion, the player had to frequently make changes in direction and rhythm with or without the ball. When the game situation required it, even playing on the bank. The test involved 3 times of $5 \mathrm{~min}$. of actual play. A series of indices that reflect the individual offensive performance have been reported in the table. Specifically, these concern 4 aspects:

- Ball control (advancing and maintaining position).

- The Passage (verticalizations and number of passages).

- The creation of offensive actions (by carrying the ball or through unmarked passages).

- The number of scoring chances (in and out of area).

\section{Statistical analysis}

The data obtained from the tests showed a normal distribution and were presented as mean and standard 
deviation (SD). A t-test was conducted for independent samples to combine the results obtained from the tests before the experiment, and after the experiment. The t-test was selected as an analytical method to verify the presence or absence of a significant difference between two sets of data. The significant level was set at $p=0.25$. Statistical analyzes were performed with the IBM SPSS Statistics 23 software.

\section{Results}

In the free trial, that of the "consecutive passages in reduced spaces" (Fig.1), the most frequent errors occurred in the hasty execution of the gesture, due to the opposing pressing which resulted in most cases, a defective control or a poorly calibrated first intention pass by the ball owner. In some cases, the difficulty in knowing how to dose the right strength to impart to the ball has also emerged. This often entailed the execution of high passages, slower and difficult to be controlled by the teammates compared to those carried out on the ground, facilitating the intervention of the defender. As can be seen from the results in the table, the number of steps carried out has increased considerably in both groups. The t-test shows a statistically significant variation between the two groups. Space is the variable that most influenced decision making and athletic performance.

In the second test, of the offensive situation with diagonally opposite doors (Fig. 2), the performance evaluation of the players was carried out with objective observation sheets. Effective and ineffective measures were considered, which provided a basis for calculating the reliability ratios (Table 2). Both teams recorded a better performance index in the rep-
Table 1. Results of the test of consecutive passes

\begin{tabular}{|c|c|c|c|c|c|c|c|}
\hline \multirow[t]{2}{*}{$\begin{array}{l}\text { Terms of } \\
\text { registration }\end{array}$} & \multicolumn{2}{|c|}{$\begin{array}{l}\text { Experimental } \\
\text { group }(n=12)\end{array}$} & \multicolumn{2}{|c|}{$\begin{array}{l}\text { Control } \\
\text { group } \\
(n=12)\end{array}$} & \multirow[t]{2}{*}{$\Delta \mathbf{x}$} & \multirow[t]{2}{*}{$\mathbf{t}$} & \multirow[t]{2}{*}{$\mathbf{p}$} \\
\hline & $\mathbf{X}$ & $\mathbf{s}$ & $\mathbf{X}$ & $\mathbf{s}$ & & & \\
\hline $\begin{array}{l}\text { Until the } \\
\text { experiment }\end{array}$ & 7.1 & 2.44 & 5 & 1.53 & 1.75 & 2.09 & .0175 \\
\hline $\begin{array}{l}\text { After the } \\
\text { experiment }\end{array}$ & 9.4 & 2.76 & 6.6 & 1.91 & 2.50 & 2.10 & .0124 \\
\hline
\end{tabular}

etition of the test, but the team that showed overall a greater efficiency index was the experimental group with a score of 7.3 (until the experiment) and 7.5 (post the experiment). In a similar study (Kaczor \& Duda, 2017) the players had reached an efficiency index of 6.18 .

In the last test of 3vs3 with limited spaces (Fig. 3), what we wanted to investigate was the execution of the individual offensive strategy. The results of the evaluation (Table 3) show a significant increase in the individual involvement of the players and at the same time, a limited execution of slow actions in the game. The most frequent mistakes made by the attackers were playing too close, almost in line and not forming a triangle, thus facilitating the defense game. Even the passage, very often, was carried out on the partner and not on the run, thus slowing the execution of the shot. With the t-test, it has been observed that the main skills in which a significant improvement has occurred concern an increase in the number of steps performed, and greater offensive danger.

Table 2. Results of the test " $3 \mathrm{vs} 3$ with elements of psychokinetic"

\begin{tabular}{lcccccccc}
\hline \multicolumn{1}{c}{ Index } & \multicolumn{2}{c}{ Efficiency index } & \multicolumn{2}{c}{ Inefficiency index } & \multicolumn{2}{c}{ Activity index } & \multicolumn{2}{c}{ Reliability index } \\
\hline $\begin{array}{c}\text { Experimental } \\
\text { group }\end{array}$ & $\begin{array}{c}\text { Until the } \\
\text { experiment }\end{array}$ & $\begin{array}{c}\text { After the } \\
\text { experiment }\end{array}$ & $\begin{array}{c}\text { Until the } \\
\text { experiment }\end{array}$ & $\begin{array}{c}\text { After the } \\
\text { experiment }\end{array}$ & $\begin{array}{c}\text { Until the } \\
\text { experiment }\end{array}$ & $\begin{array}{c}\text { After the } \\
\text { experiment }\end{array}$ & $\begin{array}{c}\text { Until the } \\
\text { experiment }\end{array}$ & $\begin{array}{c}\text { After the } \\
\text { experiment }\end{array}$ \\
\hline Goal shot & 5 & 4 & 2 & 1 & 7 & 5 & 7.1 & 8 \\
Lead the ball & 8 & 8 & 4 & 3 & 12 & 11 & 6.6 & 7.2 \\
Dribbling & 6 & 6 & 1 & 1 & 7 & 7 & 8.5 & 8.5 \\
Balls stolen & 5 & 5 & 3 & 1 & 9 & 7 & 7.7 & 7.5 \\
Total Passes & 7 & 6 & 2 & 2 & 7 & 6 & 8.5 & 6.6 \\
Receptions & 6 & 4 & 1 & 2 & 7 & 3 & 7.1 & 6.6 \\
Assuming position & 5 & 3 & 2 & 1 & & 7 & 7 & \\
\hline
\end{tabular}

Performance efficiency until the experiment: 7.3 Performance efficiency after the experiment: 7.5

\begin{tabular}{|c|c|c|c|c|c|c|c|c|}
\hline Control group & $\begin{array}{l}\text { Until the } \\
\text { experiment }\end{array}$ & $\begin{array}{l}\text { After the } \\
\text { experiment }\end{array}$ & $\begin{array}{l}\text { Until the } \\
\text { experiment }\end{array}$ & $\begin{array}{l}\text { After the } \\
\text { experiment }\end{array}$ & $\begin{array}{l}\text { Until the } \\
\text { experiment }\end{array}$ & $\begin{array}{l}\text { After the } \\
\text { experiment }\end{array}$ & $\begin{array}{l}\text { Until the } \\
\text { experiment }\end{array}$ & $\begin{array}{l}\text { After the } \\
\text { experiment }\end{array}$ \\
\hline Goal shot & 3 & 6 & 5 & 3 & 8 & 9 & 3.7 & 6.6 \\
\hline Lead the ball & 6 & 3 & 5 & 2 & 11 & 5 & 5.4 & 6 \\
\hline Dribbling & 3 & 4 & 2 & 2 & 5 & 6 & 6 & 6.6 \\
\hline Balls stolen & 4 & 3 & 5 & 4 & 9 & 7 & 4.4 & 4.2 \\
\hline Total Passes & 8 & 6 & 3 & 2 & 11 & 8 & 7.2 & 7.5 \\
\hline Receptions & 6 & 4 & 2 & 2 & 8 & 6 & 7.5 & 6.6 \\
\hline Assuming position & 4 & 3 & 3 & 2 & 7 & 5 & 5.7 & 6 \\
\hline
\end{tabular}

Performance efficiency until the experiment: $5.7 \quad$ Performance efficiency after the experiment: 6.2

Note: Efficiency index = number of effective actions; Inefficiency index = number of ineffective actions; Activity index = effective + ineffective actions; Reliability index $=($ effective actions $\div$ activity index $) \mathrm{x} 10$; Index of complex action efficiency $=($ sum of all reliability indices $) \div 7$. 
Table 3. Results of the test " $3 v \mathrm{vs} 3$ in small spaces"

\begin{tabular}{|c|c|c|c|c|c|c|c|c|}
\hline \multirow[t]{2}{*}{ Variables considered } & \multirow[t]{2}{*}{ Terms of registration } & \multicolumn{2}{|c|}{$\begin{array}{l}\text { Experimental group } \\
(\mathrm{n}=12)\end{array}$} & \multicolumn{2}{|c|}{$\begin{array}{l}\text { Control group } \\
(\mathrm{n}=12)\end{array}$} & \multirow[t]{2}{*}{$\Delta \mathbf{x}$} & \multirow[t]{2}{*}{$\mathbf{t}$} & \multirow{2}{*}{$\mathbf{p}$} \\
\hline & & $\mathbf{X}$ & s & $\mathbf{X}$ & s & & & \\
\hline \multirow{2}{*}{ Ball control } & Until the experiment & 3.8 & 0.9 & 2.9 & 0.8 & .75 & 2.58 & .017 \\
\hline & After the experiment & 4.1 & 0.5 & 3.2 & 0.4 & 1.63 & 4.32 & .000 \\
\hline \multirow{2}{*}{ Total Passes } & Until the experiment & 4.5 & 0.5 & 2.9 & 0.6 & 1.66 & 2.74 & .019 \\
\hline & After the experiment & 4.7 & 1.6 & 3.1 & 1.6 & .50 & 6.46 & .001 \\
\hline \multirow{2}{*}{$\begin{array}{l}\text { Creating goal score } \\
\text { opportunity }\end{array}$} & Until the experiment & 5.3 & 2.3 & 3.4 & 2.1 & 1.91 & 2.44 & .032 \\
\hline & After the experiment & 5.8 & 1.1 & 5.2 & 1.8 & 0.50 & 0.93 & .364 \\
\hline \multirow{2}{*}{ Shots on goal } & Until the experiment & 4.0 & 1.0 & 4.5 & 1.9 & 0.58 & -0.64 & .530 \\
\hline & After the experiment & 4.8 & 1.6 & 5.2 & 2.1 & 1.54 & -0.57 & .573 \\
\hline
\end{tabular}

\section{Discussion}

From the results, the hypothesis of the study on the effectiveness of the Brain Kinetic methodology can be refuted, since it allows to reduce the activation of redundant cortical circuits that negatively condition the motor performance in stressful conditions, increasing the visuomotor coordination necessary to adapt the motor program to the environmental conditions. By observing the results of the experimental group, we can understand how to obtain a correct execution of the most important technical gestures, players must be able to solve multiple problems that are constantly encountered in the game. By observing the results of the control group, we can see how giving priority to the technique and the precise execution of the coach's orders, through the execution of stereotyped exercises, without motivating the players looking for solutions to the problems encountered in the game, prevents young people from understanding the game in its most basic aspects (Zuber, Zibung, \& Conzelmann, 2015). Knowing that in $50 \%$ of the times the loss of ball possession occurs due to an incorrect decision making and not for a technical error, we need to reflect and be stimulated to look for new solutions in this sense (Altavilla, Riela, Di Tore, \& Raiola, 2017; Sgrò, Aiello, Casella, \& Lipoma, 2016). Exercises with limited spaces and with a reduced number of players have been presented, since the players touch the ball several times. This involves the realization of many passes, control, dribbling, shots, and rebounds, stimulating much more than football at 11 the learning of the technique by all players. According to some studies (Carvalho \& Pacheco, 1990; Leso, Dias, Ferreira, Gama, \& Couceiro, 2017), playing with the same players four 11-player soccer games and four 7-player soccer games in 2 halves of 20 minutes, the average number of contacts with the ball in 7-aside football is $92 \%$ higher than in 11 -player football. The authors who have studied the problem of internal and external load in young players have rarely referred to the possibility of using/varying the space (Kilding, Tunstall, \& Kuzmic, 2008). The dynamic modulation of the space in which the exercise is performed seems to strongly influence the high intensity exercise with a reduction of the same by about $48 \%$ and about $39.6 \%$ respectively for $\mathrm{U} 13$ and $\mathrm{U} 15$. The total distance reached also decreased in the dynamic condition for U13 and U15, respectively by $16.5 \%$ and $13.6 \%$ (Panfil \& Mazur, 2018; Sgrò, Quinto, Pignato, \& Lipoma, 2016; Partington \& Cushion, 2013). The results of these studies demonstrate the possibility of practically applying this operational monitoring tool for the individual assessment of players, since it has a real and significant impact on the result of the game. This study is offered as an additional contribution to the methodology presented, since it produces greater effects than the traditional training process to which the experimental group was subjected. As for the cognitive aspect, this work acquires a special meaning because it is the essence of a sports game. The ability to quickly and effectively adapt a learned behaviour can only be acquired when the player is subjected from the beginning, and up to the high performance phase, to a systematic development of his mental abilities (Ceruso, Esposito, \& D'Elia, 2019). These are considered, more than in the past, as the fundamental and essential skills for good performance. In view of further research, other investigations could be conducted on the identification of training protocols and tests at different ages during adolescence. It would be appropriate to compare the measures through the subsequent years of development of the participants. A possible proposal could be to identify, for those who have the possibility, directly the physiological capacities rather than relying on estimates based on performance, focusing in detail on this specific element, perhaps by administering self-efficacy questionnaires for a complete approach of self-evaluation.

\section{Conclusions}

This study allowed to experimentally test, through the use of specific field tests, the effectiveness of the Brain Kinetic training method. This allowed the players involved in the experimental group to take personal, individual and group actions that had a real impact on the outcome of the game. The essential concept that emerges is that the development of game intelligence in football necessarily passes from the ability to teach players to perceive and understand a game situation based on the knowledge and experience previously acquired, using simplified games with a increasing degree of difficulty. It doesn't matter if the action is the result of repeated practice of the same game situation, what matters is that the player is able to read the game situation and solve problems successfully.

\section{Conflict of interest}

The authors declare that there is no conflict of interest. 


\section{References}

Accame, F. (2010). La didattica del giuoco del calcio. Tecnica e tattica secondo la scuola di Coverciano [The didactics of the game of football. Technique and tactics according to the school of Coverciano]. Italy: Correre.

Altavilla, G., Riela, L., Di Tore, A.P., \& Raiola, G. (2017). The physical effort required from professional football players in different playing positions. Journal of Physical Education and Sport, 17(3), 2007-2012.

https://doi.org/10.7752/jpes.2017.03200

Battisti, E. (2018). Giovanissimi e allievi. La metodologia di allenamento. Principi ed esercitazioni per formare il calciatore [Giovanissimi and Allievi. The training methodology. Principles and exercises to train the soccer player]. Correre.

Capranica, L., \& Millard-Stafford, M. L. (2011). Youth sport specialization: how to manage competition and training? International journal of sports physiology and performance, 6(4), 572-579.

Carvalho, J., \& Pacheco, R. (1990). Ensino do futebol: futebol de 11 ou futebol de 7. Revista Horizonte, 5(25), 7-11.

Ceruso, R., Esposito, G., \& D’Elia, F. (2019). Coordination attached to the qualitative aspects of football. Journal of Physical Education and Sport, 19(s5), 1773-1776. https://doi.org/10.7752/jpes.2019.s5260

Ceruso, R., Esposito, G., \& D’Elia, F. (2019). Analysis and evaluation of the qualitative aspects of the young players. Journal of Physical Education and Sport, 19(s5), 1814-1819. https://doi.org/10.7752/jpes.2019.s5266.

D’Isanto, T., D’Elia, F., Raiola, G., \& Altavilla, G. (2019). Assessment of sport performance: Theoretical aspects and practical indications. SportMont, 17(1), 79-82. https://doi.org/10.26773/smj.190214

Esposito, G., Ceruso, R., \& D'elia, F. (2019). The importance of a technical-coordinative work with psychokinetic elements in the youth sectors of soccer academies. Journal of Physical Education and Sport, 19(s5), 1843-1851. https://doi.org/10.7752/jpes.2019.s5272

Halouani, J., Chtourou, H., Dellal, A., Chaouachi, A., \& Chamari, K. (2017). Soccer small-sided games in young players: rule modification to induce higher physiological responses. Biology of sport, 34(2), 163.

Invernizzi, P. L., Signorini, G., Bosio, A., Raiola, G., \& Scurati, R. (2020). Validity and Reliability of Self-PerceptionBased Submaximal Fitness Tests in Young Adult Females: An Educational Perspective. Sustainability, 12(6), 2265. https://doi.org/10.3390/su12062265

Izzo, R., D’Isanto, T., Raiola, G., Cejudo, A., Ponsano, N., \& Varde'i, C.H. (2020). The role of fatigue in football matches, performance model analysis and evaluation during quarters using live global positioning system technology at 50hz. Sport Science, 13(1), 30-35.

Joo, C. H., Hwang-Bo, K., \& Jee, H. (2016). Technical and physical activities of small-sided games in young Korean soccer players. Journal of strength and conditioning research, 30(8), 2164-2173.

https://doi.org/10.1519/JSC.0000000000001319

Kaczor, M., \& Duda, H. (2017). The impact of the creative model in teaching football on professional knowledge and effectiveness of players aged 12 and 13. Journal of Kinesiology and Exercise Sciences, 80(27), 27-34.

Kilding, A. E., Tunstall, H., \& Kuzmic, D. (2008). Suitability of FIFA's “The 11" training programme for young football players-impact on physical performance. Journal of sports science \& medicine, 7(3), 320.

Leso, G., Dias, G., Ferreira, J. P., Gama, J., \& Couceiro, M. S. (2017). Perception of creativity and game intelligence in soccer. Creativity Research Journal, 29(2), 182-187.

MacDougall, J.D., Wenger, H.A., \& Green, H.J. (1991). Physiological testing of the high-performance athlete (2nd ed.) Campaign: Human Kinetics.

Molinas, E., \& Argiolas, I. (2002). Tecnica e didattica delle abilità motorie del gioco del calcio [Technique and didactics of the motor skills of the game of football]. Roma, IT: Società Stampa Sportiva.

Panfil, R., \& Mazur, L. (2018). Operative game monitoring as a fundamental for a football players efficiency evaluation. Quality in Sport, 3(4), 69-83.

Partington, M., \& Cushion, C. (2013). An investigation of the practice activities and coaching behaviors of professional top-level youth soccer coaches. Scandinavian journal of medicine \& science in sports, 23(3), 374-382.

Pill, S. (2012). Teaching game sense in soccer. Journal of Physical Education, Recreation \& Dance, 83(3), 42-52.

Pill, S. (2014). Informing game sense pedagogy with constraints led theory for coaching in Australian football. Sports Coaching Review, 3(1), 46-62.

Raiola, G., D’Elia, F., \& Altavilla, G. (2018). Physical activity and sports sciences between European Research Council and academic disciplines in Italy. Journal of Human Sport and Exercise, 13(1), 283-295. https://doi.org/10.14198/jhse.2018.13.Proc2.13

Raiola, G. (2017). Motor learning and teaching method. Journal of Physical Education and Sport, 17(s5), 2239-2243. https://doi.org/10.7752/jpes.2017.s5236.

Rossi, M., Thrassou, A., \& Vrontis, D. (2013). Football performance and strategic choices in Italy and beyond. International Journal of Organizational Analysis, 21(4), 546-564.

Sgrò, F., Aiello, F., Casella, A., \& Lipoma, M. (2016). Offensive strategies in the European Football Championship 2012. Perceptual and Motor Skills, 123(3), 792-809.

Sgrò, F., Quinto, A., Pignato, S., \& Lipoma, M. (2016) Comparison of product and process oriented model accuracy for assessing countermovement vertical jump motor proficiency in pre-adolescents. Journal of Physical Education and Sport, 16(3), 921-926. https://doi.org/10.7752/jpes.2016.03145

Wein, H. (2007). Developing youth football players. Human Kinetics.

Williams, A.M., \& Reilly, T. (2000). Talent identification and development in soccer. Journal of sports sciences, 18(9), 657-667. https://doi.org/10.1080/02640410050120041

Zuber, C., Zibung, M., \& Conzelmann, A. (2015). Motivational patterns as an instrument for predicting success in promising young football players. Journal of sports sciences, 33(2), 160-168. https://doi.org/10.1080/02640414.2014.928827 


\title{
МЕТОДИКА СПРИЯННЯ РОЗВИТКУ ІНТЕЛЕКТУ ТА ІГРОВИХ НАВИЧОК У МОЛОДІЖНОМУ ФУТБОЛІ
}

\author{
Джованні Еспозіто ${ }^{1 \mathrm{ABCDE}}$, Франческа Д’Елія ${ }^{1 \mathrm{ABCD}}$, Гаетано Райола ${ }^{1 \mathrm{ABCE}}$, \\ ${ }^{1}$ Університет Салерно
}

Авторський вклад: А - дизайн дослідження; В - збір даних; C - статаналіз; D - підготовка рукопису; Е - збір коштів

Реферат. Стаття: 7 с., 3 табл., 3 рис., 30 джерел

Метою дослідження $€$ оцінка ігрових навичок молодих гравців, які досліджуються, у глобальному контексті. Зокрема, призначено перевірити, чи сприятливо вплинула запропонована методика навчання на формування ігрових навичок та підвищення ефективності ігрової діяльності.

Матеріали та методи. Учасниками дослідження $€$ 24 молоді гравці, віком від 13 до 14 років. Для досягнення поставлених завдань дослідження спиралось на такі методи: аналіз наукової літератури, польове тестування та методи математичної статистики. Експериментальна група виконувала специфічний тренувальний мезоцикл (такий, що стосується мозкової кінетики), а контрольна група - традиційний робочий мезоцикл. Для виявлення наслідків методології навчання використовувалися польові випробування як до, так і після навчального періоду, з дотриманням протоколів виконання, описаних X. Вейном. Матеріали дослідження були оброблені програмним забезпеченням статистичного аналізу IBM
SPSS 22. Для порівняння результатів двох груп використовували парний зразок $\mathrm{t}$-тесту.

Результати. Аналіз t-тесту вказує на статистично значущі зміни тренувального ефекту експериментальної групи. Кращий показник ефективності, виявлений в експериментальній групі у виконанні навичок, порівняно $з$ контрольною групою, пояснюється диверсифікацією методології, якій вони були піддані. Тому зміни після навчання на кожному індексі навичок посилюються подальшим повторенням тестів. Відмінності між показниками тесту є статистично значущими.

Висновки. Дослідження підтвердило гіпотезу про те, що використання методу тренування мозкової кінетики визначає позитивний ефект у формуванні ігрових навичок. Цей метод дозволив гравцям, які беруть участь в експериментальній групі, виконувати індивідуальні та групові дії, що реально вплинули на результат гри.

Ключові слова: молодіжний футбол, навички прийняття рішень, спрощена гра.

\section{Information about the authors:}

Esposito Giovanni: g.esposito198@studenti.unisa.it; https://orcid.org/0000-0002-3659-8943; Department of Human, Philosophical and Education Sciences, University of Salerno, Italy. Via Giovanni Paolo II, 132 - 84084 Fisciano (SA), Italy.

D’Elia Francesca: fdelia@unisa.it; https://orcid.org/0000-0003-1441-8101; Department of Human, Philosophical and Education Sciences, University of Salerno, Italy. Via Giovanni Paolo II, 132 - 84084 Fisciano (SA), Italy.

Raiola Gaetano: graiola@unisa.it; https://orcid.org/0000-0002-7659-1674; Department of Human, Philosophical and Education Sciences, University of Salerno, Italy. Via Giovanni Paolo II, 132 - 84084 Fisciano (SA), Italy.

Cite this article as: Esposito, G., D’Elia, F., \& Raiola, G. (2020). A Method to Promote the Development of Intelligence and Game Skills in Youth Football. Teorîa ta Metodika Fizičnogo Vihovannâ, 20(3), 142-148. https://doi.org/10.17309/tmfv.2020.3.03

Received: 3.06.2020. Accepted: 20.09.2020. Published: 25.09.2020

This work is licensed under a Creative Commons Attribution 4.0 International License

(http://creativecommons.org/licenses/by/4.0). 